Unity Journal

Vol. III, 232-244, 2022

Doi: https://doi.org/10.3126/unityj.v3i01.43328

Prithvi Narayan Shah Research Center

Directorate General of Military Training, Nepali Army

Kathmandu, Nepal

\title{
A Survey Study on Social Behaviors towards Nepali Army
}

\section{Bhoj Singh Khadka}

\section{Abstract}

Humans interact among themselves, and they have different perceptions of public institutions based on their individual approaches and attitudes. Behavior is an interactive product of emotion, thought, and feeling. It is usually resulted from people's perceptions and activities. Notably, social relation, welfare, accountability, rule of law, democratic culture determines the social behaviors of institutions. An in-depth study of social responses about any work or institution through social media has remained unsearched. This study aims to assess social behaviors towards Nepali Army. To fulfill this objective symbolic behaviors: happy, sad, surprised, excited and outraged on news about the Nepali Army published in Online Khabar were analyzed by deploying a quantitative research method. Out of 138 , the 28 news were found as per pre-determined news themes and used for study. The findings of the study reveals that $84.5 \%$ and 86.2 $\%$ were happy face behaviors on news on the Nepali Army's social welfares works and military diplomacy on international controversial issues respectively. Likewise, $91.7 \%$ were sad face behaviors on news on sad events for the Nepali Army. This study strongly indicates that Nepali people are satisfied with the work culture of the Nepali Army and that the Nepali Army has a high reputation in the public sphere. The study result also reveals that Army has been contributing to nation development to keep public sentiments as a central by respecting democratic principles. Good deeds have good comments or happy behaviors. Digital media comments are spontaneous; these comments judge the reputation of the institutions fairly.

Keywords: social media, social behaviors, news, reputation, Nepali Army

\section{Introduction}

The Nepali Army is an institution with a long history ever since the unification campaign in the mid-eighteenth century. It has changed its name Gorkhas to Royal Nepali Army and Nepali Army after 2006 (Nepali Army, n.d.). From the course of the last fifteen years, Nepali Army has come under the control of the elected civilian authority, which is generally called the civilian control. And, it has been working in accordance with provisions of the Constitution of Nepal for foreign and internal security, development construction, conservation of natural resources, rescue and relief in disaster and establishment of world peace. The Nepali Army is continuously performing social welfare works, security related works and peace keeping works as per constitutional mandates from its establishment. 
However, the comments, social responses on aforementioned works by public were negligible due to the lacks of digital and social media till the nineteen century. After the onset of the digital technology and social media, information technology revolution and innovation of social media, the government and governmental organizations lagged behind world of private as well as business, because of had lacked policies about digital media, but governments have changed radically since last decade (Ronfeldt, 2010, p. 243). Over the course of the last seventy years, comments through social media as well as comments on online news have become a global phenomenon. Advances in information technology have led to changes in the way face to face communication, physical protest movement, and other traditional favor and against rally are raised and disseminated, these physical present behaviors are gradually being replaced by digital media comments.

In the context of Nepal, after the establishment and reestablishment of democracy, the government of Nepal expressed its liberal policy towards the digital media, and social media, online news portal were rapidly developed in Nepal. Along these social and online portal establishments, the uses of these portals have also been rapidly increased. Now, the general public and other professional are continuously comments, responses and disseminate personal thought on work done by various organizations and government including the Nepali Army by various social media and digital forum. Social media, online news and digital portal are also cover the news of works done by various organizations including Nepali Army and allocate the space for public comments and responses. However, the responses, comments of the people to the work done by various organizations including the Nepali Army have not been studied and analyzed yet in the context of the Nepal. The personal values, beliefs, attitudes towards the specific tasks or stimuli can promote individual behavior but it is difficult known which values, recognition and choices influences the behaviors (Ajzen \& Fishbein, 1973, p. 56; Sagiv \& Roccas, 2017, pp. 3-5). But, generally people can show the happy, sad, surprised, excited and outraged responses toward the any stimuli or works as social behavior. Normally, people show the happy responses on good works that contribute to promote the reputation of individual and organizations, and sad on bad or loss or painful event.

The Nepali Army has expressed its commitment to respect the working principles: accuracy, impartiality, truthfulness, fairness, objectivity, and public accountability (Kartinawati \& Wisudawanto, 2020, pp. 2324) of media as well as online journalism. By laws, Nepali Army accepts news on its various works and activities. Moreover, it respects constructive suggestions and fair comments in social media. It also welcomes comments and responses as a major pillar of governance in its conviction that promotes the democratic culture in organization. Now, the news coverage of social welfare as well as other works done by the Nepali Army is easily seen in the various online and printed media. The Nepali Army has been contributing to the constitution, democracy, peace and stability of the country, overall development and prosperity, and foreign policy and diplomacy (Timilsina, 2020, p. 158). And it claims that these actions are being carried out under civilian control and with good civil relations. However, there are no any rigid independent evidences behind how majority of general public perceive and behave to these works 
done by army. Therefore, this study was carried out to examine and explore the social behaviors towards the Nepali Army through the analysis of symbolic responses on news related to Nepali Army publish in Online Khabar news portal with the help of the behaviorism theoretical concept of human beings.

\section{Literature Review}

Humans basically intend to maintain and rely on affection, interaction and cognition which are three capacities of human are interrelated to each other. Affects are the emotions we experience as part of our daily lives. As our day progresses, we may feel happy or sad, jealousy or gratitude, pride. Emotions play an adaptive role in helping us control social behavior (Jhangiani \& Tarry, 2014, pp. 19-22). Likewise, the interaction may influence others if we have to communicate our feelings effectively. We interact with others to get benefits as well as satisfaction from exchange of idea, goods and services to others (Kameda et al., 2003, p. 2-3). A number of psychologists have call cognition is the mental activity of information processing and use this information to make decisions. Social cognition is related to social activities that help us understand and predict the behavior of ourselves and others. Human are very intelligent and use cognition in every part of their social life such as respond to others, making decision, comments on others' actions, etc. (Jhangiani \& Tarry, 2014, pp.45-46). The behavior is a technique of communicating thoughts, needs or desires in response to the environment or actions or information. It also allows communication beyond words. The ability to respond is assisted by a sense of personal control. When people believe they can take instrumental action to fix an issue, they are more likely to do so and feel more committed to their decision. The perceived behavior is concerned with personal action control or agency (Bandura, 1992, p.355; Schwarzer \& Renner, 2000, pp. 487-488). Before executing or responding, the individual acquires or stores information and processes it. The individual processes information in a similar way to computer systems (Miller, 1956, p. 81). The specific response or behavior toward the stimuli such as news about military is the result of the critical analysis of information. In the critical analysis, obtaining, assessing, and selecting information as well as exploring a variety of possible solutions in order to have a deeper understanding of a situation, lastly uses the best action (Ennis, 1989, p. 4). The general public, various professionals and intellectuals can respond and comments to the actions and news done by the organization and government officials, and these responses or comments may also be rational. Some authors have also suggested that environmental, genetic, and psychological variables are the three basic categories of variables that determine behavior. And, these three categories are also somehow accelerating from attitude, beliefs and self-efficacy (Peters \& Crutzen, 2017, pp.1-3). Based on the above described scholarly literatures, it is explicated that the public comments and behaviors on the news of works done by various institutions including Nepali Army are done spontaneously; these comments judge the reputation of institutions fairly. Of course, good deeds have good comments or happy behavior. People get self-satisfaction after giving response, so they respond according to prevailing social norms and values or rules. Theoretically as well as practically, it is explicit that humans have behaved to others based on the stimuli nature and it is widely accepted. Reasoned Action Approach (Fishbein \& Ajzen, 2010), 
Stimulus Response Theory (Thorndike, 1999), operant conditioning theory (Skinner, 1938), and other theories are aimed to explaining behavior. Each of these theories applies to a particular behavior. For example, the Reasoned Action Approach describes reasoned action, and the Stimulus Response Theory describes the response to stimuli. Often need to combine some theories to behavioral explanations. There are various theories on the behaviorism but key themes of all theories are study of the human behaviors.

\section{Stimulus Response Theory}

Stimulus response theory is a psychological concept related to the belief that behavior appears as a result of stimulus-response interactions. In particular, it is believed that the subject is given a stimulus and then responds to that stimulus, thereby producing "behavior." In other words, behavior cannot exist without some kind of stimulus, at least from that point of view (Thorndike, 1999, pp23-56). He also believed that the association between the stimulus and response be stronger by rewards, however punishment has role to lose the relation. In the context of the social psychology, personal gratification, social recognition, etc. may be considered as a reward. People comment on online social media news about military, here online news represents the stimulus and comments response. The happy, sad, outraged, etc. behaviors are the result of stimulus response interaction. These behaviors (comments on news) are accelerated as result of personal satisfaction as well as social recognition. In addition, conditioning also describes the concept of stimuli and responses very concisely. This is because it shows how to produce a predictable and consistent response to a person with very little stimulus. Generally, response is not arising in the unknown stimulus. For example, rural Nepali people do not response or no show behavior on the Hot dogs (food items), however, salivate when see the Sel Roti (food item), that is because of conditioning. Likewise, happy face comments on the news of good social works and sad face comments on the news of corruption are also result of conditioning.

\section{Reasoned Action Approach}

The Reasoned Action Approach describes that attitudes towards behavior, perceived norms, and perceived behavioral control determine people's intentions, and that people's intentions predict their behavior. It suggests that a person's behavior is determined by the intent to carry out that behavior, which is a function of behavior and attitude towards subjective norms (Fishbein \& Ajzen, 2010, 20-36). It aims to clarify the relationship between attitude and behavior in human activity. It is primarily used to predict how an individual will behave based on existing attitudes and emotions. A person's decision to engage in a particular action is based on what he or she expects as a result of performing that action. The social norms and values are also contributing the people whether or not show the behavior. The human behavior is result of attitudes but result of that behavior, social norms and values may assist to behaviors. So, generally people cannot behave against the social norms as well as truth. For example, majority of the general Nepali people and various professionals are not do happy face comments on news about rape acted by the high personality because the rape is socially restricted, and is sin. Likewise, it is believed that the comments on the news of the social welfare works done by government as well as organization including the military are commented as per reasoned action and rational. 
The literature review shows that generally the any behavior based on attitude and subjective norms, attitude is due to the personal rational and logic.

\section{Operant Conditioning Theory}

The operant conditioning theory is developed from the Thorndike's law of effect. The basic principle of operant conditioning is that behaviors that are reinforced strengthen and are more likely to occur again in the future. Actions that result in unfavorable punishment or consequences, on the other hand, will be weakened and less likely to occur again in the future (Skinner, 1938, pp.102-123). Generally, Skinner (1938, pp.433-480) described that there are three types' behaviors: first neutral operant that neither increase nor decrease the behaviors from the environmental stimulus. Secondly, reinforce that may increase repeating of the behavior from the environmental stimulus and thirdly, punisher that may decrease or weaken the behaviors from the environmental stimulus. The behavior is generally affected from the reinforcement and punishment. In the context of the social behaviors on the social media news about the Nepali Army, the personal gratification and social norms, values are considered as reinforcement or punishment to strengthening or weaken behaviors. The personal gratification from the works of the Nepali Army public are happily behaved, conversely personal irritation or dissatisfaction works public are sadly behaved.

Behaviorism is mainly concerned with observable behavior, and argued that internal events like thinking, beliefs, values, and emotion may promote the behaviors. The environment or stimulus is key influencer of human behaviors. Behaviorism focuses on how we learn or behave in specific ways or stimuli. Of particular interest to this study is the utilization of behaviorism concept. The theoretical literature review shows that humans rationally respond to stimuli. However, in the context of Nepal, empirical review of the literature shows that there is very little research on digital comments to assess the behaviors towards the institutions. The key question guiding this study is in regard to the behaviors on digital media news behaved by the public. This study tried to explores the social behaviors towards Nepali Army by using the digital media behaviors on works news of Army. 


\section{Conceptual Framework}

Predictor Variables- Works

Done By Nepali Army

- Social Welfares Works

- Military Diplomacy on International Controversial Issues

- Sad and Loss

\begin{tabular}{|l|}
\hline \multicolumn{1}{|c|}{$\downarrow$} \\
Public Symbolic \\
Responses/Behaviors on News \\
\hline - Happy \\
- Sad \\
- Surprised \\
- Outraged \\
\hline
\end{tabular}

\section{Outcome Variables- High/Low} /No Reputation

\section{Percent of Symbolic Behaviors}

- High percent of happy face behaviors on social welfares works and military diplomacy on international controversial Issues

- High percent of sad face behaviors on sad and loss

- High percent of sad, surprised, and outraged face behaviors on social welfares works and military diplomacy on international controversial Issues

- High percent of happy, and excited face behaviors on sad and loss
Nepali Army has Low or no Reputation in Social sphere/ Public are Not Happy from the Works of Nepali Army

Fig 1: Conceptual Framework 


\section{Methodology}

The current trends of disseminating personal thought through the social media and virtual world served as the catalyst for this study. With beginning of twenty first century pro and anti-protest are started also digitally. A fruitful place to begin this study is with published online news about Nepali Army that was commented by general Nepali people, professional, intellectual, officials, etc. The concept of a quantitative survey research design with a cross sectional nature and positivist paradigm was used to carry out this study. A quantitative research is outlined in the specific occurrence or process or scientific mathematical operational phenomenon and it is also more appropriate in terms of timing (Blackstone, 2014, pp. 28-28). Nardi (2018, pp. 4-8) mentioned that survey research on human social behavior and attitudes is process of gathering information from a sample and generalizing results of sample to a huge similar population. This design is used for many reasons, including exploring, describing, explaining, and evaluating for the purpose of understanding an issue in depth, arriving at decisions, and making predictions. Likewise, Lindell and Whitney (2001, p. 114) argued that a cross-sectional study examines data from a group of people at a single point in time. It is a type of observational research that's also known as descriptive research. The inflating of correlations in cross-sectional studies of attitude-behavior interactions is subject to common method variance, so this strategy also recommends questionnaire design processes as well as careful analysis to improve the precision of this adjustment. This study seeks to analyze the symbolic behaviors which were commented in the news about the Nepali Army, for this archival data depository of https://www.onlinekhabar. com during a period from 15 June 2017 to 15 July was used. This proceeds in two stages: first, all news published during this period about the Nepali Army were collected, and these news were separated as per predetermined three news themes-social welfare works, military diplomacy on international controversial issues and sad or loses events. Second, the symbolic comments- happy, sad, surprised, excited and outraged on the news were ensured and counted as per three news themes. Out of 138 , the 28 news were in three predetermined themes, all these 28 news were comprised as a sample of the study, rest of news were about vacancy announcement, military court decision, taking oath, presence of army in different ceremony, and invitation to another country's chief of military, and these news were excluded from the study. The themes wise aggregation analysis of symbolic comments of 20 news of social welfare works theme, 5 of military diplomacy on international controversial issues and 3 of $\mathrm{n}$ sad or loses were done.

The percent of three news themes wise symbolic comments on the all 28 news was calculated by the MS excel. The results of the themes wise news was interpreted with the concept of behavioral theories to find the social behaviors of Nepali towards the Nepali Army. On the basis of percent of happy, sad, surprised, excited and outraged the reputation as well as relation of the Army in social sphere was analyzed. Moreover, the symbolic behaviors or responses on the particular news heading was analyzed and also discussed this result to assess the actual behaviors of people towards the particular works of Nepali Army.

\section{Result}

The result has been presented as per predetermined three news themes- social 
welfare, military diplomacy on international controversial issues, and sad or lose event in the three tables.

The table 1 represents behaviors of Nepali people towards the works done by Nepali Army through the published news about social works done. Of the total average 84.5 percent people were showed happy face behaviors on the social works news. And, more than 66 percent people were happy on the 18 news of social works, however, less than 50 percent people were happy on the 2 news. Which were on business works of Nepali Army. Likewise, the table 2 shows behaviors of the Nepali people on the works and voices of Nepali Army on military diplomacy on international controversial issues, which showed total average 86.2 percent people, were happy on current Nepali Army's diplomacy, and 2 percent people were sad.

The table 3 shows behaviors of Nepali people on sad and loses event for Nepali Army, that total average 91.7 percent of Nepali people were sad on sad news for Nepali Army. However, 0.7 percent people were showed the excited behaviors on these sad or lose or painful event of news. The cent percent people were sad on the news of human loses in Nepali Army during the accident.

Table No. 1: Social Behaviors on News of Social Welfare Works Done by Nepali Army

\begin{tabular}{|l|l|l|l|l|l|l|}
\hline \multirow{2}{*}{ SN } & \multirow{2}{*}{ News Headings } & \multicolumn{3}{|l|}{ Percentage of Social Behaviors on the News } \\
\cline { 3 - 8 } & & Happy & Sad & Surprised & Excited & Outraged \\
\hline 1 & $\begin{array}{l}\text { Isolation is being made at Geta Medical } \\
\text { College, Nepali Army has started work }\end{array}$ & 96 & & 4 & & \\
\hline 2 & $\begin{array}{l}\text { Nepali Army launches Safa Himal' } \\
\text { campaign }\end{array}$ & 96 & 4 & & & \\
\hline 3 & $\begin{array}{l}\text { Business complex in Mahankal to } \\
\text { expand hospitals in the state: Nepal } \\
\text { Army }\end{array}$ & 40 & 8 & 4 & & 48 \\
\hline 4 & $\begin{array}{l}\text { Nepal Army is bringing 28 tons of } \\
\text { medical supplies from China }\end{array}$ & 90 & 3 & 3 & 1 & 3 \\
\hline 5 & $\begin{array}{l}\text { The Nepali Army started building an } \\
\text { integration memorial garden in the } \\
\text { Jitpur }\end{array}$ & 85 & 5 & & 12 & 2 \\
\hline 6 & $\begin{array}{l}\text { The Nepali Army is responsible for the } \\
\text { construction of the Ghantibagar-Tinker } \\
\text { section }\end{array}$ & 86 & & & 12 & \\
\hline 7 & $\begin{array}{l}\text { Nepali Army bringing medicine worth } \\
\text { of NRs. 2 million from India }\end{array}$ & 79 & 3 & 12 & & 6 \\
\hline
\end{tabular}




\begin{tabular}{|c|c|c|c|c|c|c|}
\hline 8 & $\begin{array}{l}\text { A dummy quarantine was set up in the } \\
\text { Bhadrakali by the Nepali Army while } \\
\text { training in corona treatment }\end{array}$ & 93 & 4 & 2 & & \\
\hline 9 & $\begin{array}{l}\text { Nepali Army subsidy Store in } \\
\text { Tripureshwor }\end{array}$ & 46 & 11 & 18 & 3 & 23 \\
\hline 10 & $\begin{array}{l}\text { Nepali Army is conducting various } \\
\text { programs to make the visit year } 2020 \text { a } \\
\text { success }\end{array}$ & 94 & & & 6 & \\
\hline 11 & $\begin{array}{l}\text { The Nepal Army built a bridge over the } \\
\text { Bangari River in Bara }\end{array}$ & 90 & & 5 & 5 & \\
\hline 12 & $\begin{array}{l}\text { Nepali Army begins sanitation in } \\
\text { Everest }\end{array}$ & 94 & 3 & & & 3 \\
\hline 13 & $\begin{array}{l}\text { Nepali Army making temporary shelter } \\
\text { for those affected by the storm }\end{array}$ & 92 & 4 & 1 & 2 & 2 \\
\hline 14 & $\begin{array}{l}\text { Preparations to hand over the rest of the } \\
\text { Melamchi's work to the Nepal Army }\end{array}$ & 66 & 11 & 9 & 4 & 10 \\
\hline 15 & $\begin{array}{l}\text { Army in corpse management: Malami } \\
\text { in difficult times }\end{array}$ & 93 & 5 & 1 & & 1 \\
\hline 16 & $\begin{array}{l}\text { In Ghantibagar, the army made Goreto } \\
\text { and Chhangru residents easy to come to } \\
\text { the district headquarters }\end{array}$ & 96 & & & 4 & \\
\hline 17 & $\begin{array}{l}\text { Army builds school building in the } \\
\text { Gorkha }\end{array}$ & 83 & & & 17 & \\
\hline 18 & $\begin{array}{l}\text { In Bhaktapur, the army made isolation } \\
\text { of } 225 \text { beds }\end{array}$ & 89 & 6 & 3 & & 3 \\
\hline 19 & $\begin{array}{l}\text { The army has set up a temporary } \\
\text { quarantine in the Doti }\end{array}$ & 93 & & 7 & & \\
\hline 20 & $\begin{array}{l}\text { Army in charge of quarantine site in } \\
\text { Province } 1\end{array}$ & 89 & & & & 11 \\
\hline \multicolumn{2}{|r|}{ Average Grand Total \% } & 84.5 & 3.35 & 3.45 & 2.7 & 6.1 \\
\hline
\end{tabular}

Table No. 2: Social Behaviors on News of Military Diplomacy on International Controversial Issues 


\begin{tabular}{|l|l|l|l|l|l|l|}
\hline \multirow{2}{*}{ SN } & News Headings & \multicolumn{6}{|l|}{ Percentage of Social Behaviors on the News } \\
\cline { 3 - 8 } & Happy & Sad & Surprised & Excited & Outraged \\
\hline 1 & $\begin{array}{l}\text { The Nepali Army said that the news in } \\
\text { the Indian media was just propaganda }\end{array}$ & 85 & 2 & 2 & 2 & 9 \\
\hline 2 & $\begin{array}{l}\text { Nepali Army's response to the US: We } \\
\text { are able to face terrorism }\end{array}$ & 92 & 1 & 3 & 1 & 2 \\
\hline 3 & $\begin{array}{l}\text { Our team will not leave Libya: Nepali } \\
\text { Army }\end{array}$ & 93 & 1 & 2 & 2 & 1 \\
\hline 4 & $\begin{array}{l}\text { Nepali Army launches Himal } \\
\text { Darshan-4 operation in trilateral } \\
\text { border area }\end{array}$ & 83 & 6 & 3 & & 8 \\
\hline 5 & $\begin{array}{l}\text { Chief of Army Staff's reply to Narwane } \\
\text { after seven months }\end{array}$ & 78 & & 5 & 6 & 11 \\
\hline
\end{tabular}

Table No. 3: Social Behaviors on News of Sad or Loses Events for Nepali Army

\begin{tabular}{|l|l|l|l|l|l|l|}
\hline SN & News Headings & \multicolumn{5}{|c|}{ Percentage of Social Behaviors on the News } \\
\cline { 3 - 7 } & Happy & Sad & Surprised & Excited & Outraged \\
\hline 1 & $\begin{array}{l}\text { One killed, six injured in Nepali Army } \\
\text { vehicle accident }\end{array}$ & 100 & & & \\
\hline 2 & $\begin{array}{l}17 \text { Nepali Army personnel injured } \\
\text { when bus overturns in Kawasoti }\end{array}$ & 2 & 93 & & & 3 \\
\hline 3 & $\begin{array}{l}\text { In Gorkha, a tipper hit an army vehicle, } \\
\text { injuring five soldiers }\end{array}$ & 3 & 82 & 3 & 1 & 10 \\
\hline \multicolumn{2}{|c|}{ Average of Grand Total } & $\mathbf{1 . 7}$ & $\mathbf{9 1 . 7}$ & $\mathbf{1 . 0}$ & $\mathbf{0 . 3}$ & $\mathbf{4 . 3}$ \\
\hline
\end{tabular}

\section{Discussion}

The comments on actions done of Nepali Army through the various online news as well as social media may also one of the important indicators to examine the reputation of Nepali Army in social sphere, and or satisfaction of Nepali people towards their actions of Nepali Army. The status of public behaviors on actions of Nepali Army will be discussing respectively. The public behaviors on the actions of Nepali Army can be explored the real public relation of Army. In totality in the sample news of the study, 84.5 percent Nepali people were happy face behaviors on the news of social work done by Nepali Army. (Barakoti, 2020, p. 89) concluded that Nepali Army is and should remain open, accessible and politically neutral and the Army should continue its social welfare works in both inside and outside the country to maintain the public relation. Generally, social welfare is process or action that make change the life of common people positively through the 
different intervention, people are do respond (conditioned) to happily on good actions (stimulus). The finding was exactly supported with the Skinner (1950, pp. 193-195) that behaviors that follow desired outcomes are more likely to be repeated and behaviors that follow undesirable outcomes are less likely to be repeated. In this sense, operant conditioning depends on a very simple premise: behavior followed by reinforcement will become stronger and more likely to happen again in the future. The heading wise news analysis reveals that happy behaviors are repeatedly seen in the 18 social welfare works of Nepali Army, out of 20. Gyawali (2021, p. 41) mentioned that Nepali Army has a lot of potentiality to contribute to the development; can be used for infrastructure development. It is believed that Nepali Army is still running social welfare works with its own rule of law rather than political decisions. However, it is also suspected that Nepali Army could be weak if the major post appointments and actions are as per lobbying of political ideology. Therefore, civil society and independent right holders have been emphasizing totally and accurately implementation of constitutional provisions in regards of Nepali Army mobilization and development. The result also indicates that of the total percent of people, the $6.1 \%$ people expressed their outrage in the social works of Nepali Army. The heading wise analysis clearly showed that the percent of outraged be up to $6.1 \%$ due to high outraged behaviors on news of expand of business complex and subside shop of Nepali Army. Normally, it may assume this percent is nominal, but we speculate that this might be symbolic opposition to the involvement of the Nepali Army in commercial activities.

Similarly, the study also reveals that more than 86 percent $(86.2 \%)$ people were happy on the current military diplomacy and diplomatic voices of Army officials. This percent indicates that Nepali Army is capable to maintain the balance relation to other countries with equal respect and status. Bhattarai (2020, p. 48) argued that Nepali Army as an established institution of the country has reaffirmed its synergic ability to practice modern diplomacy in both at neighborhood and abroad. The results on military diplomacy also showed that 6.2 percent people were outraged in current diplomacy of Nepali Army. Our findings on military diplomacy at least hint that not cent percent people are happy, there is space for improvement. Ghimire (2020, p. 130) suggested that Nepal should build synergic bond between national security, and development polices then after strengthening military diplomacy in different strategic regional as well as foreign level. From the general public perspective, the current military diplomacy and diplomatic voices are well but should be make excellent in the forthcoming days.

Furthermore, the study shows that 91.7 percent people were sad on the sad or lose event or a painful event for the Nepali Army. The cent percent sample people were showed the sad behaviors on news of the death on the Nepali Army in the road accident. The 4.3 percent people were outraged on the painful event for Nepali Army, The analysis clearly showed that outraged behaviors is high in the accidents, so this may outrage on driving process.

\section{Conclusion}

In the present era to raise the favors and oppose voices in various stimulus through the digital and social media are tremendously increased; communicating pattern is shifted 
physical to virtual. The comments and symbolic comments on the news of actions of Nepali Army may significant indicators to examine the social behaviors towards Nepali Army. The majority of people are practicing fairly and personally responses on the actions done by Nepali Army. The study indicates that more than 84 percent respondents are happy from the current working style of Army. The Nepali people have widely accepted that Nepali Army is working to keep public sentiments as central by respecting democratic principles and analyzing geopolitical scenario. Hence, the result of this study may be useful to Nepali Army to continue and change their present work scope.

\section{References}

Ajzen, I., \& Fishbein, M. (1973). Attitudinal and normative variables as predictors of specific behaviors. Journal of Personality and Social Psychology, 27(1), 41-57. https://doi. org/10.1037/h0034440

Bandura, A. (1992). Self-efficacy mechanism in psychobiologic functioning. In R. Schwarzer (Ed.), Self-efficacy: Thought control of action, 355-394. Hemisphere Publishing Corp.

Barakoti, M. (2020). Reviewing the civil military relations in Nepal. Unity Journal, 1, 89-95. https://doi.org/10.3126/unityj.v1i0.35698

Bhattarai, G. (2020). Assessing Nepal's Military Diplomacy: Neighborhood and beyond. Unity Journal, 1, 48-56. https://doi.org/10.3126/ unityj.v1i0.35694

Blackstone, A. (2014). Principles of Sociological Inquiry: Qualitative and quantitative methods. Saylor Foundation. https://resources.saylor. org/wwwresources/archived/site/textbooks/ Principles $\% 20$ of $\% 20$ Sociologica $1 \% 20$ Inquiry.pdf
Ennis, R.H. (1987). Critical thinking and subject specificity: Clarification and needed research. Educational Researcher, 18(3), 4-10. https:// doi.org/10.3102/0013189X018003004

Fishbein, M., \& Ajzen, I. (2010). Predicting and Changing Behavior: The Reasoned Action Approach. Taylor \& Francis Group. https:// doi.org/10.4324/9780203838020

Gyawali, B. (2021). Importance of the Development Army in the context of Nepal. Unity Journal, 2, 41-53. https://doi. org/10.3126/unityj.v2i0.38807

Ghimire, P. (2020). Nepal's Military Diplomacy: Retrospect and Prospect. Unity Journal, 1, 120-125. https://doi.org/10.3126/unityj. v1i0.35702

Jhangiani, R., \& Tarry, H. (eds.). (2014). Principles of Social Psychology. BCcampus. https://opentextbc.ca/socialpsychology/

Kameda, T., Takezawa, M., \& Hastie, R. (2003). The logic of social sharing: An evolutionary game analysis of adaptive norm development. Personality and Social Psychology Review, 7(1), 2-19. https://doi. org/10.1207/S15327957PSPR0701_1

Kartinawati, E., \& Wisudawanto, R. (2020). The implementation of basic principles of journalism in citizen journalist's news on NETCJ. Journal ASPIKOM, 5(1), 11-26. http://dx.doi.org/10.24329/aspikom.v5i1.539

Lindell, M. K., \& Whitney, D. J. (2001). Accounting for common method variance in cross-sectional research designs. Journal of Applied Psychology, 86(1), 114-121. https:// doi.org/10.1037/0021-9010.86.1.114

Miller, G. A. (1956). The magical number seven, plus or minus two: Some limits on our capacity for processing information. Psychological Review, 63(2), 81-97. https://doi.org/10.1037/ h0043158 
Nardi, P.M.(2018). Doing survey research: A guide to quantitative methods (4 $4^{\text {th }}$ ed.). Routledge. https://doi.org/10.4324/9781315172231

Nepali Army. (n.d.). History of the Nepali Army. https://www.nepalarmy.mil.np/page/history

Peters, G-J. Y., \& Crutzen, R. (2017). Pragmatic nihilism: how a theory of nothing can help health psychology progress. Health Psychology Review, 11(2), 103-121. https:// doi.org/10.1080/17437199.2017.1284015

Roccas. S., \& L. Sagiv, L. (eds.). (2017). Values and behavior: Taking a cross cultural perspective. Springer. https://doi.org/10.1007/978-3-31956352-7 1

Ronfeldt, D. (1992). Cyberocracy is coming. The Information Society, 8(4), 243-296. https:// doi.org/10.1080/01972243.1992.9960123
Schwarzer, R., \& Renner, B. (2000). Socialcognitive predictors of health behavior: Action self-efficacy and coping self-efficacy. Health Psychology, 19(5), 487-495. https://doi. org/10.1037/0278-6133.19.5.487

Skinner, B. F. (1938). The behavior of organisms: an experimental analysis. Appleton-Century.

Skinner, B. F. (1950). Are theories of learning necessary? Psychological Review, 57(4), 193216. https://doi.org/10.1037/h0054367

Thorndike, E. L. (1999). Education Psychology: Briefer course. Routledge. https://doi. org/10.4324/9781315009735

Timilsina, A. (2020). Nagarik- sainik sambandha: Bartaman awastha, chunauti ra abasar. Unity Journal, 1, 58-64. https://doi.org/10.3126/ unityj.v1i0.35994 